\title{
10
}

\section{Nature, culture and time: Contested landscapes among environmental managers in Skåne, southern Sweden}

\section{Lesley Head}

Australian Centre for Cultural Environmental Research (AUSCCER), University of Wollongong, NSW, Australia

Ihead@uow.edu.au

\section{Joachim Regnéll}

Kristianstad University, Kristianstad, Sweden

\section{Introduction}

Our increased understanding of 'Man's Role in Changing the Face of the Earth' (Thomas 1956) is one of the key scientific achievements of the second half of the 20th century. Human activities now appropriate more than one third of the Earth's terrestrial ecosystem production, and between a third and a half of the land surface of the planet has been transformed by human development (Vitousek et al. 1997). Humans are inextricably embedded in all earth surface processes, and often dominate them. These findings are increasingly being recognised in political and policy spheres, most notably in contemporary debates about climate change (IPCC 2007). Peter Kershaw's work has been an influential component of this achievement, particularly in alerting us to a much longer potential timeframe of human entanglement through huntergatherer use of fire. He has forced us to think differently about cultural landscapes, and his research findings have persistently challenged the ideal of pristine wilderness.

Although research now clearly shows the variety of ways in which culture and nature are closely embedded, to the point of challenging their constitution as separate entities, most Western jurisdictions still attempt to manage them separately. For example, environmental management frequently distinguishes between natural heritage, managed by biological scientists, and cultural heritage, managed by archaeologists and related professionals. There are many spatial implications of this dualistic approach: 'sites' or 'reserves' tend to be conceptualised 
and managed separately from their broader landscape context; and cultural and natural heritage values tend to be opposed rather than complementary. Where humans are constituted as not belonging to nature, they and their activities are physically excluded from protected areas. This has had particular implications for indigenous peoples, who have often been excluded from their own country. The management challenges of the 21st century require us to take integrative approaches to landscape management, cognisant of both human and nonhuman activities and processes, and scales from local to global. An important but relatively undeveloped area of research is to understand how environmental managers in government bureaucracies are experiencing and negotiating these challenges.

In this paper, we focus on managers of the landscapes of the county of Skåne, southern Sweden. This is the most densely occupied part of Sweden and preserves a visible signature of human activity dating back thousands of years. It is the sort of place for which the term 'cultural landscape' was coined (Birks et al. 1988; Sporrong 1995; Emanuelsson et al. 2002). Although it is somewhat contested, there is strong evidence in the environmental history of southern Sweden that these forests have developed in the past few thousand years, with agricultural activities, particularly grazing, as an integral part of them (e.g. Berglund 1969, 1991; Cooper 2000; Bradshaw 2004, 2005; Bradshaw and Lindbladh 2005). Environmental histories in this region are built up from a combination of palaeoecological work and historical geography using old maps. If dualistic approaches to the management of culture and nature persist in such a demonstrably hybrid context as the cultural landscapes of Skåne, it demonstrates their resilience, and it is extremely significant to wider international debates. On the other hand, if alternative approaches are being developed here, there may be lessons for other parts of the world that are still using a separationist paradigm.

The main methodological window we use in the paper is interviews with professional environmental managers employed by the County Administrative Board (Länsstyrelsen), bearing responsibility for the management of nature reserves and cultural heritage management. Although environmental managers are powerful agents in decision-making and policy about such landscapes, there has been little systematic analysis of their understandings and practices.

We first contextualise our approach using recent culture/nature debates in geography and related disciplines. We then provide more specific background to the Swedish environmental context. An outline of the legislative and bureaucratic context of environmental management in Sweden shows how the situation in which these environmental professionals work already imposes certain divisions on them.

We then explain our methodology and focus on the results of interviews in which we analysed how these professionals negotiate questions of nature and culture in their work. These negotiations occur differently in relation to different habitats/landscapes. We compare forests and traditional agricultural landscapes, showing that the attraction of the primeval remains strong in relation to deciduous forests.

\section{Dualistic and hybrid approaches to human-nature relations}

In parallel to the accumulating scientific evidence of pervasive human influences in earth system processes, there has been substantially increased interest within the humanities and social sciences in non-human worlds. Ideas of hybridity and networks are being utilised to more effectively understand interactions between culture and nature, or more specifically to dissolve the distinction between them. The most well-known recent elaboration of ideas of hybridity has been in the work of Haraway (1991), Latour (1993) and Whatmore (2002) and their attempts to break free of the binary categories of society and nature. A further influence 
on these debates in the past few decades has been the increasing political voice of indigenous peoples. Indigenous people's struggle for representation has become an important influence on thinking about environment, nature and landscape (Howitt et al. 2006).

The clearest example of the critique of nature converging on a practical environmental issue is in the postcolonial reassessment of the wilderness ideal and associated environmental imaginaries (Cronon 1996; Head 2000; Braun 2002; Baldwin 2004). Definitions of wilderness have a long history of change, and a shift from negative to positive connotations. The 19th century romantic wilderness ideal - of timeless, unchanging and remote landscapes underpinned conservation and national parks policy in frontier societies such as the United States and Australia over the past century. The challenge came from diverse lines of evidence, including palaeoecological and archaeological demonstrations of long histories of human occupation in changing environments, and indigenous voices for whom so-called wilderness areas are home (McNiven and Russell 1995; Langton 1998). In Australia, the settler encounter with indigenous understandings of land and country has profoundly challenged management frameworks (Howitt 2001; Adams 2004, 2008; Howitt and Suchet-Pearson 2006). One management response has been the development of 'cultural landscapes' as a land management category, as seen, for example, in the World Heritage listing process (Head 2010).

The power of the wild has been exerted not only in New World contexts where indigenous inhabitants could be conceptually and physically erased. Mels $(1999,2002)$ has shown how it informed the establishment of national parks in Sweden, with problematic consequences for both the Saami lands of the Arctic north (see also Beach 2001,2004), and the forest parks of Skåne, such as Söderåsen. Mels argues that the concept of nature promoted in national parks and through the Swedish EPA ${ }^{1}$ is one heavily informed by biological science views that exclude humans. The park principle 'remains committed to an image of parks as spaces of natural science rather than social convention' (Mels 1999:174). Parks such as Söderåsen, Stenshuvud and Dalby Söderskog had long histories of cultural engagement and transformation, indeed were 'to a substantial degree the product of human practices' (Mels 1999:170). They responded in unexpected ways to management plans that fenced them and left them to take care of themselves.

How can the national parks of Skåne be defined as natural landscapes requiring careful protection from human intervention, while simultaneously needing active management to maintain a pastoral condition, to remove "unnatural" species and to provide unobstructed scenic viewpoints? Or should the parks and their nature be seen as cultural products? This alternative would bring about insurmountable problems for the park ideal, because its nature by definition is of a "natural", not "cultural" kind. (Mels 1999:173)

Participants in our study work mostly with nature reserves rather than national parks, but there are a number of areas of comparison with Mels' work. The national context, which he identified as extremely important, has also changed somewhat in recent years, with much habitat and species management now subject to European Union commitments such as Natura 2000 .

It is beyond the scope of this paper to resolve the long-standing dualisms in Western thought. Rather, we explore how both the dualisms and challenges to them are being experienced and negotiated in the working lives of these environmental managers. As Castree argues:

$1 \quad$ Naturvårdsverket 
The baroque jargon of academia may confidently declare that there never was a Maginot line dividing natural things from social things. But in several walks of life people continue to speak and act as though such a divide were self-evident... there is a continuing need for close analysis of nature-talk in any and all realms of society. (Castree 2004:191)

By focusing here on a particular set of 'nature-talk', we illustrate the practical challenges that lie ahead of all of us. We can also identify the organisational and disciplinary spheres of influence where separationist ideas remain spatially powerful.

\section{The Swedish context}

\section{Legislation}

There are two major sets of laws covering Swedish landscape management, Miljöbalken, the Environmental Code, and Kulturminneslagen, the Heritage Conservation Act. The conservation of areas, species of plants and animals are regulated by the Environmental Code, whereas the conservation of ancient remains, churches, other buildings, and place names are within the Cultural Heritage Law (for overviews in English see Ministry of the Environment, Sweden (2000); National Heritage Board, Sweden (2000)).

In the Environmental law section 2, chapter 7, Nature conservancy, there are three major instruments of spatial conservation.

- National parks (\$2-3) are areas owned by the state for the purpose of preserving larger areas of a certain landscape type in their natural or in all essentials unchanged conditions.

- Nature reserves ( $\$ 4-8)$ have the purpose of preserving biodiversity, conserving valuable nature areas or meeting the demands of outdoor recreation.

- Cultural reserves ( $\$ 9)$ have the purpose of preserving valuable cultural landscapes.

Swedish legislation concerning nature conservation was established in 1909 with the formation of nine national parks, ranging from large remote mountain areas in northern Sweden to small deciduous woodlands in southern Sweden. All were supposed to be 'natural' areas, with no or only slight interference by humans, and were therefore not to be managed in any way. A new nature conservation law in 1965, Naturvardslagen, introduced the concept of nature reserves, and in 1967 the Swedish Environmental Protection Agency (Naturvårdsverket ${ }^{2}$ ) was formed.

In 1999, the parliament established 15 environmental objectives to emphasise the change from defensive politics against environmental threats such as pollution, to offensive politics, with the aim of handing over to the next generation a society where environmental problems had been solved. To reach these objectives, a large number of environmental laws were revised and brought together in the Environmental Code. Various national authorities are in charge of the objectives and the broader issues related to the objectives. The Swedish EPA is, for example, responsible for the 'natural environment', while the National Heritage Board is in charge of the 'cultural environment'. And the Swedish Board of Agriculture rules the objective 'A varied Agricultural landscape', whereas the Swedish Forest Agency is responsible for 'Sustainable

$2 \quad$ Naturvård and naturskydd are two Swedish terms which both may be translated nature conservation. However, the word skydda, means 'protect, shelter, defend', while vårda means 'take good care of' (with a slightly more positive meaning than the word sköta, which means 'manage', 'take care of'). Naturskydd is the older term from 1904, while naturvård did not come into use until 1958 (the Swedish National Encyclopedia). 
Forests'. As most Swedish landscapes combine elements of several of these interests, for example where the forests have been part of the agricultural economy for thousands of years, there is considerable overlap between the interests of the conservation authorities. This overlap in responsibilities provides potential for both fruitful cooperation between managers of different backgrounds, and also conflict. A 16th objective, on biodiversity, was adopted in 2005 (SEOC 2006).

\section{Organisation}

Most of the policies of the national authorities are implemented at the regional level by 21 county councils. In county Skåne, this means that the issues of 'natural' and 'cultural' environment are handled within the Nature Conservation Section (Naturskyddssektionen) and the Culture Conservation Section (Kulturmiljösektionen) of the Environmental Department (Miljöavdelningen), while agricultural issues are managed by the Agricultural Department (Jordbrukssektionen). Forestry issues, including forestry measures within protected areas, are handled by the regional offices of the Swedish Forest Agency (Skogsstyrelsen), which are not located at the county councils.

When it joined the European Union in 1994, Sweden also signed EU nature legislation, including the Habitats Directive. Article 3 of this directive states that 'a coherent European network of special areas of conservation shall be set up under the title Natura 2000'. There are now more than $60,000 \mathrm{~km}^{2}$ of Natura 2000 sites in Sweden, from the alpine in the north, through the boreal zone, to the nemoral zone of southernmost Sweden. The Natura 2000 concept is presented to the public as follows:

Not all kinds of habitats and species of Natura 2000 can be preserved in the same way. Management will vary depending on which kind of values are to be preserved. Sometimes active management or restoration is needed, sometimes no alterations should be made. The basic principle is that a meadow should remain a meadow through mowing, while the forest will continue to develop to natural forest by being excluded from forestry. (Naturvårdsverket 2003) (translated to English by JR)

This provides an interesting example of a theme that reappears in our interview material - how the open cultural landscape (grasslands) is contrasted to the supposedly natural forest landscape.

\section{Methods}

The now well-established tradition of qualitative research into environmental values and behaviours in cultural geography, anthropology and related disciplines has produced analyses of different, often conflicting understandings of nature (Harrison and Burgess 1994; Trigger 1997; Trigger and Mulcock 2005; Gill 2006) between groups, as well as wider societal discourses (Dekker Linnros and Hallin 2001). Important recent studies have examined environmentalists (McGregor 2004). Among the wide range of groups that can be considered stakeholders in environmental issues, managers and bureaucrats within government agencies are among the least studied. An important Nordic exception is Emmelin's (2000) questionnaire study of professional cultures within Nordic environmental administrations.

Our interviewees came from the Nature Conservation Section (Naturskyddssektionen) and the Culture Conservation Section (Kulturmiljösektionen) of the Environmental Department (Miljöavdelningen). The initial research strategy was to compare the experiences and thinking of 'nature' and 'culture' professionals working in broader landscape management, where a 
clear nature/culture delineation was likely to be problematic. We undertook semi-structured interviews with 13 people from these sections, identified by their section directors as having responsibility for landscape issues and reserve selection and management policy. Although small in number, this represents an almost complete sample of the designated group, the exceptions being several people who were on leave or otherwise unavailable during the interview period, the winter of 2005-06. Interviews were done in the offices of Länsstyrelsen in Malmö and Kristianstad.

Ten were seen by themselves and their colleagues as 'nature people', three as 'culture people', the proportion reflecting the dominance of nature people in issues to do with landscape management. (We excluded cultural heritage managers with exclusive responsibility for building conservation.) Nature people tended to have an educational background in biology, ecology and/or physical geography, while culture people had studied archaeology, history and/or cultural geography. A number of individuals had generalist backgrounds. There was a mixture of ages, from recent graduates to an imminent retiree, and nine men and four women. Such direct and full access was only possible with the support of the section directors, although they declined to be interviewed themselves. This unique research opportunity also created some dilemmas. For example, participants were aware that although they would be formally anonymous, their colleagues would likely be able to identify their opinions. All were happy to proceed on this basis, a number stating adamantly that they would stand by their statements.

Interviews were conducted in English by the two authors, who bring both outsider and insider perspectives to the Swedish situation in general, and to Skåne environments in particular. Initial questions covered participants' training and background, their current job responsibilities, landscape management strategies, the ways the culture/nature distinction is important (or not) in their work environment, departmental organisation, and issues of scale (county/nation/EU). Questions about specific examples they had worked on were used to lead into more conceptual discussions. Interviewees were all well educated in English, but were encouraged to switch to Swedish when necessary. Interviews were transcribed in full, sections translated into English as needed, and analysed for the dominant themes, which are discussed below. The terms nature (natur) and culture (kultur) have more or less parallel meanings in Swedish and English, but a number of other terms needed conceptual as well as linguistic clarification. These are explained in the following sections as necessary.

\section{Nature and culture}

All interviewees expressed great passion for their work and commitment to the broader endeavour in which they were engaged. Most expressed frustrations of one sort or another at the bureaucratic and legislative barriers to effective work. A number had suggestions about how the organisation could work better to manage landscapes in a more integrated way. The widespread feeling of being understaffed, overworked and frequently reorganised would be shared in many similar organisations today. As one participant laughed when asked how his thinking had changed over time, 'As I said, I haven't had time to think.'

Many could trace their involvement in environmental work to childhood experiences of country life, and/or involvement in community environmental organisations. All recognised the complexities of nature/culture entanglements, with a variety of different positions on whether and where a line should be drawn between them. We outline the diversity of views here, and then show how they are expressed in particular environments.

\section{Nature nature and culture nature}

There was a strong sense among participants of the pervasive and long-term influences of 
humans on the Skåne landscape. This has led to a vernacular expression that 'there is no nature in Skåne'. ${ }^{3}$ While participants did not usually go to those lengths, most saw Skåne as having a different sort of nature. The relevant comparison was either spatial - the north of Sweden, where 'real' nature is considered to still exist; or temporal - a past time before significant human impacts. These distinctions were summarised by one participant as 'nature nature' (untouched nature, in the north), 'nature culture' (natur parverkad = impacted nature, nature formed by people) (this includes avenues, fields, grazing areas, meadows, stone walls, open ditches and earth walls, i.e. a variety of agricultural situations that have become important contexts for biodiversity preservation), and 'culture culture' (cultural heritage sites such as houses, buildings, churches, archaeological sites).

The middle ground idea of 'nature culture', or 'culture nature', had a variety of expressions in the interviews, coming from both nature and culture people:

all nature is human made, at least in this province... people have used the landscape during the... last 10,000 years.

a natural landscape doesn't exist in this part of Sweden.

I don't think there is so much nature in Skåne... I think you have to go to the north of Sweden to see nature... that doesn't have as much impact from human beings... because all the woods are in some way cultivated.

In Skåne, where you have high cultural values, you also have high nature values, many times, they're connected... also in the forest, not only in the grass land.

All made reference to the history of the landscape and its utilisation by people, first as hunter gatherers but more particularly as agriculturalists. One identified the enclosure period as the relevant temporal boundary, with traditional land uses before that time falling under the umbrella of 'nature'. The relationship with humans can also change the status of non-humans, as in the example 'horses are nature when grazing, but culture when someone is riding them'. Despite the acknowledged entanglements between nature and culture, only two participants mentioned the possibility of nature being in the city.

There was a widespread feeling that the difference between a naturreservat (nature reserve) and kulturreservat (cultural reserve) is a purely administrative one, the only difference being that nature reserves rarely include buildings. Many argued that there should just be one type of reserve in which both natural and cultural features could be protected. For example, 'it's not necessary to point out whether it's a nature reserve or a culture reserve, it's just a reserve, because all nature is humanmade, at least in this province'. Differences arose, however, in the specifics of management, whether inside or outside reserves. The dilemmas of managing various aspects of the continuing human presence leads to a set of contested landscapes, the most contested of which are the deciduous forests:

beech forest, they're cultural in Skåne... they are no more natural than rapsfält [a field of oil seed rape].

Although we did not pursue it in the interviews, and do not explore it further in this paper, it is worth noting that the ideal of a pristine, untouched nature in the north of Sweden is itself

3 Det finns ingen natur i Skåne. 
a highly contested notion.

It's a little bit different, between northern and southern Sweden, because in the north, I think... most land is nature in that case, but in the southern part, we have just a small piece of nature and the rest is the humanmade landscape.

For example, such views erase the presence and aspirations of Saami people (or include them in nature) (Beach 2001, 2004) and also ignore the agro-industrial nature of forestry in the boreal forests. This wilderness ideal can be seen to represent 'a flight from history' in much the same way as Cronon has argued for colonial societies such as the USA (Cronon 1996; see also McNiven and Russell 1995 for Australia).

\section{The deciduous forests}

The most contested of the landscapes under discussion are the deciduous beech and oak forests, confined in Sweden to the more temperate areas of the far south. For this and other reasons, including its time as part of Denmark, Skane is often referred to as the most 'continental' part of Sweden. Preservation and restoration of these deciduous forests is high on the EU agenda given their decimation in most areas of continental Europe.

Despite a long history of human occupation, interaction and transformation, forests are more likely than open landscapes to be thought of, or managed, as 'nature nature'. The main exception is the cultural heritage people, and some older ecologists with long practical management experience. This distinction was argued by one participant to be reinforced by the (northern) Stockholm perspective of Naturvårdsverket, under the influence of traditional understandings of biology:

Naturvairdsverket don't see humans as a natural part..., especially not when it comes to forest habitats. The grassland, they understand that they do need to have humans that have cattle and so on, but they don't see the human as a natural part of the dynamics of a forest.

Southern forests are seen as different to northern taiga ones because the human activities have led to the characteristics that are now valued:

[the northern ones have] been impacted but the values you have there are not dependent on the impact of humans, on the contrary.

The differences between the northern boreal and southern deciduous forests are further seen in the way people used the following terms. Urskog - old wood, untouched forest, primeval forest - was seen not to exist any more. Naturskog is natural forest, or a nature wood. 'Nature wood is a wood that hasn't been used by man for a very, very, very long time, but we don't actually have those forests in Skåne, in Sweden maybe up in the mountains.' Some of the study participants see themselves as trying to re-establish naturskog, forest with a minimum of human impact, in order to still have biologically interesting forest. Betesskog (wood pasture, or grazed forest) is seen as the most cultural type of forest, or as one person described it, a 'fruit garden' for pigs:

the main purpose with the beech trees was to produce acorns/mast [for] the pigs in the 
forest... They were similar to a fruit garden, after the same principles the acorns were central in that type of management... timber, [was] not so important.

The idea of some forests as agricultural landscapes, as described above, is not widely favoured. The same participant showed us a cartoon he uses regularly in seminars that summarises the critique that he feels he has to defend against. The caption translates as '(Enclosed) wood pasture is a bad mixture of forest and pasture not good for either trees or cows'. Thus the conceptual purity of the forest is maintained by excluding both humans and their grazing animals.

\section{Fri utveckling}

The concept of fri utveckling (= free development $=$ hands off management $)$ is an important key to understanding the differences in attitude and practice. The concept is frequently used in the guidelines for the county councils regarding management plans for Natura 2000 areas. All deciduous-forest habitats of Sweden, with the exception of ' 9070 Fennoscandian wood pastures', are supposed to be managed by the hands-off regime (Naturvardsverket 2007), sometimes, however, with the somewhat contradictory advice to clear areas around light-demanding large oaks.

In contrast to detailed discussion of the forest history, where both the long continuity of human influence in the forest and late 19th and 20th century changes in the forested landscape (such as the introduction of forestry and the decline in forest grazing) are described, free development is more promoted than discussed. A specific example of this lack of discussion, when linking the description of former land use and biological values to the proposed management style, is the management plan of the national park Söderåsen. After saying that $45 \%$ of the area contains cultural elements such as ancient fields, clearance cairns and stone walls (p. 10), the first stated aim of the national park is to protect the 'natural vegetation' for 'free, natural development' (p. 11) (Naturvårdsverket 2003).

Invoking the currency of biodiversity, plant ecologists among our sample were particularly keen to allow mixed deciduous forests to develop without human interference. The pressure to do this came not only from Naturvairdsverket but from the requirements to fulfil Natura 2000 .

We have to leave a lot of forest for internal dynamics or free development, sort of. To come closer to a natural state of forest... no large extraction of wood, increasing the dead wood in the area, and having a forest with several layers... so going from one farm-like forest to... what could be emerging to be a natural forest.

The opposite view, held mostly by the cultural heritage people, is that beech forest left to its own devices will change to something else. If you want it to stay as a beech forest, it is necessary to actively intervene, through grazing, for example. They see the biologists as denying the long cultural history of the forests. The cultural heritage people want to preserve the history of the forests, but increasingly feel they have to use the language of biodiversity to support their arguments. Thus they talk about a different suite of species being protected under a managed forest regime. The National Heritage Board has also promoted the concept of 'biological culture-heritage' (biologiskt kulturarv) during recent years to include the biological remains of former land-use meadows, pollards and grazed forest (e.g. Emanuelsson 2003).

In fact, even those who were in favour of re-establishing multi-aged forest stands recognised that fri utveckling was not, in fact, free or hands off, but another type of management: 
In the main part of Sweden you get most of the values if you leave the [spruce and pine] forest alone, but down here it's not so, it's not that easy to decide what will be the best in the long run, because you have the hands of man all over the landscape, and it's been so for a very long time.

A number of participants felt that, whatever the rhetoric, fri utveckling was in fact favoured because it is cheaper.

\section{Preserving the past ws hurrying up nature}

Although several of the 'nature tribe' refer in an almost romantic sense to forests before people, there is, as discussed in the introduction, little empirical support for this view in the environmental history of southern Sweden. In fact, the cultural people were more likely to invoke the past in forest management discussions, with the plant ecologists more often referring to the present and the future. In a context where environmental issues are understood as urgent, the ecologists see a need to reestablish this biodiversity more quickly than the several hundred years it might otherwise take. Thus they talk about the 'fast development of the natural' and 'hurrying up nature'. In another instance, an ecologist said that she did not think often of the people who had lived there in the distant past. 'I'm more interested in animals and the present, I see more that than I see ... the people before.'

There is also debate over whether this means a new sort of nature is being created.

The grazing disturbance is very important I think, because if you are leaving it to free development, you are creating [a] type of landscape of which we know very little, and [which] is completely new. The grazing disturbance has a very, very long continuity, and I think it's very important from many aspects.

For another nature person, the establishment of such new communities was important because Skåne is the only part of Sweden where climatic conditions allow the possibility of deciduous forest:

To keep some areas, we would like to suggest that the areas should develop freely, with[out] any management plan, and that would be... natural forest, not a virgin forest, because we don't have virgin forests in this part of the country...

(Interviewer) Is it creating something new then...?

Yes, no it's quite new, well it existed during the Bronze Age, perhaps, but not later, because it has been used by people during all the time... We have to start from the beginning.

Restoration work was seen as urgent, and also as requiring investment in areas of currently low biological value but with great potential.

We have to start with forests that today are used for forestry, and... with very low biodiversity, to be able to create a high diversity, because it takes about one hundred years to reach that stage of forest development, but we can't wait until, let's say, until 2015 to start with that work, because in that case those areas that we today are interested in are gone, or have developed in another direction. 
They acknowledged a need to educate the public about what would become a multi-aged forest, since more open, managed and tidy forests are very popular for recreational purposes, particularly in spring.

Sometimes we get in conflict with friluftslivet ${ }^{4}$ because we want to have a lot of dead wood for the insects and the bugs and we need to have big old trees lying everywhere but people that are going out with the dog for a walk... they like a beech forest with high nice trees and so on, and the sun.

Time in the job and lengthy field experience influenced nature people towards favouring more hands-on management.

The people that work with the management of nature reserves ... outside... see what happens... they think that it should be managed much more than those that are working with the plan... but I think it's changing.

\section{The traditional agricultural landscape}

The more obviously agricultural landscape is the area referred to as culture nature or nature culture. We distinguish here between two parts of this landscape: first, grazing areas and meadows, in which there is widespread acceptance of the need to maintain traditional practices, or some proxy thereof, in order to maintain biodiversity; and second, human constructions such as stone walls, which have become sites of biodiversity maintenance and are contested in terms of whether they should be managed for this or for cultural heritage.

\section{Grazing lands and hay meadows}

There is widespread recognition among ecologists that traditional management, or some replica thereof, is important to biodiversity conservation in the so-called semi-natural grasslands.

The main reason for restoring these man-made grasslands is their exceptionally high species richness at small spatial scales... A prerequisite for keeping high species richness is to continue grazing, as the number of species drastically decline on grasslands when abandoned. (Lindborg 2006:957)

These open environments were the least contested among our participants, who all acknowledged the integral role of cultural activities. For example, one passionate animal ecologist with current responsibility for developing the management plan for a nature reserve in coastal grasslands talked of the importance of maintaining grazing in order to prevent reed encroachment on important bird habitat.

... apart from all the plants that you wouldn't have there because the reed is so tall... the waders are dependent on... the short grass for foraging and... breeding... This marsh land here is so special, so like the highest values is for... when it comes to animals, the waders, to keep them.

$4 \quad$ Outdoor recreation. 


\section{Cultural remains as biodiversity habitat}

More contested are avenues, stone walls, open ditches, earth walls and pollarded trees, all of which are obviously the outcome of past human activity. Because of their longevity in the landscape they have become, or protect, habitats supporting biodiversity. The cultural people consider the nature people to be appropriating these remains to the domain of nature, with insufficient recognition of their cultural heritage value. One of our discussions concerned the example of avenues of trees (allés).

You have the trees, they are planted by man... with one purpose... it's a very big part of an open landscape, you see them [from a] long [way]. But these trees are not part of culture any more, it's nature now... When we want to preserve this avenue or... take down some trees, we can say OK, we think you should have that kind of tree and not that one, we are all the time on... nature's area, we have to play with the nature people, but they are making the final decision.

For this participant, responsibility for failing to recognise these more vernacular parts of the cultural landscape lay with the government who, in the laws of 'biotopskydd' (biodiversity protection), had designated such remains important for biodiversity. By the same token, their cultural significance is not necessarily recognised in the cultural heritage law, which focuses on buildings and archaeological sites more than 100 years old.

An ecologist recognised the cultural remains (earth walls, pollarded trees, mounds) in the landscape she was responsible for, but 'those things don't really have to be managed in any different way, they are just kind of there'. These remains were contentious not only in what should be done about them, but in an organisational sense, with both nature and culture people accusing the others of neglecting or not understanding them.

The different attitudes to forested and open agricultural landscapes have some parallels in two societal discourses of resistance to the Öresund Link between Sweden and Denmark (Dekker Linnros and Hallin 2001), suggesting they are indicative of more widely entrenched understandings. The first, referred to as 'Fertile Earth', emphasises 'conservation of soil as an important resource for future agriculture' (Dekker Linnros and Hallin 2001:394). It is grounded in a vision of Skåne 'where small-scale, dispersed patterns of settlement and a 'balanced' relationship with nature are the prerequisites for achieving a 'Good Society' (p. 396)'. The second, 'Protect Nature', calls for the protection of original, untouched nature. Although this discourse does not include a narrative about society, it is reinforced by the (human) spatial practice of 'being out in nature'. For example, some of the strongest advocates of this discourse are members of the Field Biologists. Although Dekker Linnros and Hallin were discussing these discourses in relation to Skåne as a whole, rather than particular environments within it, it is clear that the forest continues to be a site, perhaps the last possible site, where the Protect Nature discourse has purchase.

\section{Currencies}

Knowledge and understanding of environmental history was not in itself broadly accepted as a basis for future management strategies, so several people commented that they had to make their arguments for continuation or reestablishment of historical practices using the currency of species protection. For example, one advocate of grazing practices explained how his argument for putting cattle in a nature reserve was strengthened by the discovery that the beetle 
läderbagge (Osmoderma eremita) was favoured in other areas by more open forest conditions. In these situations, it could often become a contest between different suites of species. Plant communities were considered to be treated as more important in the management plan process than a holistic view of landscape, and more important than ancient remains.

Cultural people felt they had no equivalent of IUCN red-listed (threatened) species, nor of quantitative measures of significance. While a large number of buildings are protected by the law of 'byggadsminne' (built heritage), there was argued to be a lack of strong laws 'in the middle', for the cultural landscape.

When you're dealing with a cultural landscape, you're not dealing with objects, one there and one there, you have communication between all parts of the landscape... I think it's easier to just pick one tree or one forest or something like that but we have to deal with the structures and the... process in the landscape.

This was also connected to what was seen as the greater political power of nature and the nature people, which went along with greater funding.

On the other hand, nature people saw themselves as having considerably broadened their perspective in the past decade or so. Whereas in the past they had focused on flora and perhaps birds, today's understanding of biodiversity was seen as much broader, considering "sites that are important to beetles, butterflies, birds, mushrooms, lichens, mosses' as well.

Species are also the currency of labour allocation, since each endangered species needs an action plan. One participant said with some weariness, 'in Skåne, we are privileged with approximately 100 of these action plans'. While this is seen as an advance over times in the past when biodiversity values were not recognised at all, it would sometimes be preferable 'to look at a higher level at the landscape':

If you look at meadows, you have a vast diversity of species that are threatened, each of these gets their own action plan instead of the habitat getting an action plan. So if you are trying to save one species, you are threatening another. For example, we have Crex crex, 'kornknarr' which is a bird that likes meadows in a degenerating phase, but in the same place you have a lot of plants, that need yearly management, so they have a problem!

\section{Conclusions}

Dualistic conceptions of nature and culture remain firmly entrenched in the management of Skåne landscapes, although there are also sources of challenge.

Sweden's legislation and administrative organisation provides the setting for significant divisions between nature and culture. Both 'nature people' and 'culture people' demonstrated an understanding of Skåne as a hybrid landscape that has experienced human entanglement and influence over many thousands of years. In contrasting this with the north of Sweden, both groups demonstrated the power of an ideal, untouched (or less touched) nature existing somewhere else. Culture people and nature people differed most obviously in how they used the past and invoked time. Culture people tended to value the past for its own sake and as a guide to future activity. Nature people's temporal reference was more often the future, including when this involved creating new landscapes and forests. In this respect, they recognised and acknowledged the role of humans in contemporary management practice. None of our participants was a passionate advocate of fri utveckling, if this is understood as completely 'hands off' management. Where they were in favour of a version of it, they recognised it as a 
managed process involving considerable human investment. Those who opposed it included nature people whose many years of field experience had led them to see human activities in forests as essential to both biodiversity and cultural protection. Each group was inclined to conceptually appropriate contested areas such as stone walls for their respective 'sides', but in practical management terms, the barriers to working together on these sorts of sites do not seem insurmountable. Their perspectives have been shown to be influenced by educational background, childhood experiences and grappling with practical issues on the ground in the course of their work.

However, there are differences in the way different landscapes are understood. There is greater resistance to recognising the reality of the human role in forests and wooded landscapes than open landscapes such as grasslands and meadows. The ideal of the primeval virgin forest so powerful in popular culture holds sway among science-oriented environmental managers beyond what can be argued on the historical evidence. We speculate that it is connected to the power of trees in both scientific and popular imaginations (Jones and Cloke 2002), and to the more visible connection between open landscapes and human activity in the form of agriculture.

The historical power of 'nature' as traditionally understood within the biological and ecological sciences, relative to culture history, has been exacerbated by EU agreements such as Natura 2000, which focus on the (non-human) species as the relevant currency. This is a somewhat paradoxical outcome given that traditional understandings of nature are often argued to set humans apart from and above the rest of the natural world. The intention of such agreements has been the protection of vulnerable species in rapidly changing landscapes across national and other boundaries. It would be counterproductive, however, if increasingly separationist approaches to particular species' protection occurred at the expense of dynamic and resilient total landscapes.

To return to the theme of the volume, Peter Kershaw's work has been influential in international thinking about peopled landscapes and the challenges of the Anthropocene. Given the importance of disciplinary background as an influence on our research participants, one clear implication is on how we train future managers. It is increasingly recognised within ecology that past frameworks and conceptual understandings need revision to meet the challenges of the future (e.g. Hobbs et al. 2006, 2009). A variety of disciplinary perspectives will continue to be important, enhancing the capacity of students to approach wider crosscultural issues. There are no simple solutions to these challenges, but understanding how they play out in different organisational settings will continue to be an important complement to palaeoecological research.

\section{Acknowledgements}

This research was undertaken when LH was King Carl XVI Gustaf Visiting Professor of Environmental Sciences at Högskolan Kristianstad, Sweden. We thank Högskolan Kristianstad for financial and logistic support. We thank all our interviewees for their enthusiastic participation.

\section{References}

Adams, M. 2004. Negotiating nature: collaboration and conflict between Aboriginal and conservation interests in NSW. Australian Journal of Environmental Education 20:3-11.

Adams, M. 2008. Foundational Myths: Country and Conservation in Australia. Transforming Cultures eJournal Vol. 3 No. 1. 
Baldwin, A. 2004. An ethics of connection: social-nature in Canada's boreal forest. Ethics, Place and Environment 7:185-194.

Beach,H.2001.World Heritage and Indigenous Peoples - the Example of Laponia. In: Sundin, B. (ed), Upholders of Culture Past and Present (Royal Swedish Academy of Engineering Sciences (Kungl. Ingenjörsvetenskapsakademien-IVA) pp. 90-98. Stockholm: Elanders Gotab.

Beach, H. 2004. Political ecology in Swedish Saamiland. In: Anderson, D. and Nuttall, M. (eds), Cultivating Arctic Landscapes. Knowing and Managing Animals in the Circumpolar North, pp. 110-123. New York: Berghahn Books.

Berglund, B.E., 1969. Vegetation and human influence in South Scandinavia during Prehistoric time. In: Berglund, B.E. (ed), Impact of Man on the Scandinavian landscape during the Late Post-Glacial. Oikos Suppl 12:9-28.

Berglund, B.E. (ed), 1991. The cultural landscape during 6000 years in southern Sweden - The Ystad project. Ecological Bulletins 41.

Birks, H.H., Birks, H.J.B., Kaland, P.E. and Moe, D.E. (eds), 1988. The cultural landscape: past, present and future. Cambridge: Cambridge University Press.

Bradshaw, R.H.W. 2004. Past anthropogenic influence on European forests and some possible genetic consequences. Forest Ecology and Management 197:203-212.

Bradshaw, R.H.W. 2005. What is a natural forest? In: Stanturf, J.A. and Madsen, P. (eds) Restoration of Boreal and Temperate Forests, pp. 15-30. Boca Raton: CRC Press.

Bradshaw, R.H.W.,Hannon, G.E. and Lister, A.M. 2003. A long-term perspective on ungulatevegetation interactions. Forest Ecology and Management 181:267-280.

Bradshaw, R.H.W. and Lindbladh, M. 2005. Regional spread and stand-scale establishment of Fagus sylvatica and Picea abies in Scandinavia. Ecology 86:1679-1686.

Braun, B. 2002. The Intemperate Rainforest. Nature, Culture, and Power on Canada's West Coast. Minneapolis: University of Minnesota Press.

Castree, N. 2004. Nature is dead! Long live nature! Environment and Planning A 36:191-194.

Cooper, N.S. 2000. How natural is a nature reserve?: an ideological study of British nature conservation landscapes. Biodiversity and Conservation 9:1131-1152.

Cronon, W. 1996. The trouble with wilderness; or, getting back to the wrong nature. In: Cronon, W. (ed), Uncommon Ground, pp. 69-90. New York: W.W. Norton.

Dekker Linnros, H. and Hallin, P.O. 2001. The discursive nature of environmental conflicts: the case of the Öresund link. Area 33:391-403.

Emanuelsson, M. 2003. Skogens Biologiska Kulturarv: Att Tillvarata Föränderliga Kulturvärden. Stockholm: Riksantikvarieämbetet.

Emanuelsson, U., Bergendorff, C., Billqvist, M., Carlsson, B. and Lewan, N. 2002. Det Skånska Kulturlandskapet. Lund: Naturskyddsföreningen i Skåne.

Emmelin,L.2000.Nordiskmiljöförvaltnings professionskulturochnågraaktuellafrågeställningar i miljöpolitken. (Professional Culture in the Nordic Environmental Administrations and Some Current Issues in Environmental Policy.) Tidskrift for samfunnsforskning 41:3.

Gill, N. 2006. What is the Problem? Usefulness, the cultural turn, and social research for natural resource management. Australian Geographer 37:5-17.

Haraway, D. 1991. Simians, Cyborgs, and Women. London: Free Association Books.

Harrison, C. and Burgess, J. 1994. Social constructions of nature: a case study of conflicts over the development of Rainham Marshes. Transactions, Institute of British Geographers NS 19:291-310.

Head, L. 2000. Second Nature. The history and implications of Australia as Aboriginal landscape. Syracuse: Syracuse University Press.

Head, L. 2010. Cultural Landscapes. In: Hicks, D. and Beaudry, M. (eds), The Oxford Handbook 
of Material Culture Studies. Oxford: Oxford University Press, pp. 427-439.

Hobbs, R.J., Arico, S., Aronson, J., Baron, J.S., Bridgewater, P., Cramer, A.A., Epstein, P.R., Ewel, J.J., Klink, C.A., Lugo, A.E. and USDA F.S. 2006. Novel Ecosystems: theoretical and management aspects of the new ecological world order Global Ecology and Biogeography $15: 1-7$.

Hobbs, R.J., Higgs, E. and Harris, J.A. 2009. Novel ecosystems: implications for conservation and restoration. Trends in Ecology and Evolution 24:599-605.

Howitt, R. 2001. Frontiers, Borders, Edges. Liminal Challenges to the Hegemony of Exclusion. Australian Geographical Studies 39:233-245.

Howitt, R., Connell, J. and Hirsch, P. (eds), 2006. Resources, Nations and Indigenous Peoples. Oxford: Oxford University Press.

Howitt, R. and Suchet-Pearson, S. 2006. Rethinking the building blocks: ontological pluralism and the idea of 'management'. Geogr. Ann. 88B:323-335.

IPCC 2007. Climate Change 2007: Climate Change Impacts, Adaptation and Variability. Summary for Policymakers. Working Group II Contribution to the Intergovernmental panel on Climate Change Fourth Assessment Report. http://www.ipc.ch/(Accessed 7.4.07).

Jones, O. and Cloke, P. 2002. Tree Cultures. The place of trees and trees in their place. Oxford: Berg.

Langton, M. 1998. Burning Questions: Emerging Environmental Issues for Indigenous Peoples in Northern Australia. Centre for Indigenous Natural and Cultural Resource Management, Northern Territory University, Darwin.

Latour, B. 1993. We Have Never Been Modern. New York: Harvester Wheatsheaf.

Lindborg, R. 2006. Recreating grasslands in Swedish rural landscapes - effects of seed sowing and management history. Biodiversity and Conservation 15:957-969.

Mels, T. 1999. Wild landscapes: the cultural nature of Swedish national parks. Doctoral Thesis. Lund University Press.

Mels, T. 2002. Nature, home and scenery: the official spatialities of Swedish national parks. Environment and Planning D: Society and Space 20:135-154.

McGregor, A. 2004. Sustainable development and 'warm fuzzy feelings': discourse and nature within Australian environmental imaginaries. Geoforum 35:593-606.

McNiven, I. and Russell, L. 1995. Place with a past: reconciling wilderness and the Aboriginal past in World Heritage areas. Royal Historical Society of Queensland Journal 15:505-19.

Ministry of the Environment (Sweden) 2000. The Swedish Environmental Code, Ministry Publication Series, Ds 2000:61.

National Heritage Board (Sweden) 2000. Heritage Conservation Act (SFS1998: 950). pdf file at http://hilebrand.raa.se/laws/hcact.asp

Naturvårdsverket 2003. Natura 2000 Värdefull natur i EU. Leaflet 91-620-8131-4, 16pp.

Naturvårdsverket 2007. Naturvårdsverket skog1rev.pdf and skog2rev.pdf (http://www. naturvardsverket.se/sv/Arbete-med-naturvard/Skydd-och-skotsel-av-vardefull-natur/ Natura-2000/Vagledning/Art--och-naturtypsvisa-vagledningar-for-Natura-2000-/ (Accessed June 2007)).

Sporrong, U. 1995. Swedish Landscapes. Stockholm: Swedish Environmental Protection Agency.

Swedish Environmental Objectives Council (SEOC) 2006. Sweden's Environmental Objectives - buying into a better future, De Facto 2006. A progress report from the Swedish Environmental Objectives Council. Stockholm: SEOC.

Thomas, W.L. (ed), 1956. Man's Role in Changing the Face of the Earth. Chicago. University of Chicago Press. 
Trigger, D. 1997. Mining, landscape and the culture of development ideology in Australia. Ecumene 4:161-180.

Trigger, D. and Mulcock, J. 2005. Forests as spiritually significant places: nature, culture and belonging in Australia. The Australian Journal of Anthropology 16:306-20.

Vitousek, P.M., Mooney, H.A., Lubcheco, J. and Melillo, J.M. 1997. Human domination of earth's ecosystems. Science 277:494-499.

Whatmore, S. 2002. Hybrid Geographies. London: Sage. 